\title{
Public space and alcohol advertising: Exploratory study of the role of local government
}

\author{
Greg Swensen \\ University of Western Australia, School of Law, Perth, Western Australia
}

\begin{abstract}
The paper argues that local government bodies in Western Australia, which have a long-standing key role in overseeing public health standards and regulating business activities, potentially have a major, but under-recognized, capability to regulate the promotion and advertising of alcohol in public places overseen by them. It is contended that because local government bodies already possess extensive statutory powers to undertake this function, there is a compelling case for them to actively regulate alcohol advertising as they "own” most of the public space in Australian cities and towns.
\end{abstract}

As the proposition would involve the prohibition of alcohol advertising, this could mean that local authorities may balk at assuming this responsibility due to a possible loss of revenue if they have already issued licenses to companies to construct and maintain key parts of the public infrastructure, like bus shelters, seating, and other street furniture, in return for being able to charge fees for advertising on these facilities.

It is contended that local government authorities would ably perform a front-line role in regulating alcohol advertising in public places because of their reliance on community-based processes of consultation and decision-making for planning, in addition to understanding this role as an extension of a long standing role concerned with the advancement of public health and traffic safety.

\section{Introduction}

The social and economic benefits of the use of alcohol to the community can be squandered due to its significant health, social, and law and order consequences, which in Australia, has been estimated to cost the economy A \$36 billion per annum (Glance \& Pettigrew, 2014). These consequences have justified the need of regulatory frameworks to regulate alcohol, as it is no "ordinary commodity" (Babor et al., 2010), and to protect citizens from engaging in excessive consumption or being indirectly harmed from others' use of alcohol.

This paper explores how local government could play a greater role in the regulation of the placement and content of alcohol advertising in public places in Western Australia (WA) by the use of statutorily supported policies and enactments. This approach, if adopted, would be a paradigm shift in the current system of industry-managed regulation of advertising, which was established by the Australian Broadcasting Control Board in 1970 when it set out core principles to be followed by commercial television stations. This was underpinned by a statutory provision in Section 99 of the Broadcasting and Television Act 19421969 that a licensee "shall provide programmes and shall supervise the ... televising of programmes from his station in such manner as to ensure, as far as practicable, that the programmes are in accordance with standards determined by the Board" (Australian Broadcasting Control Board, 1975). The adoption and continued reliance on a model of industry self-regulation of alcohol advertising is not a uniquely Australian approach, for a similar system has operated in the United States since the mid-1950s (Pennock, 2007).

In addition to a clear legislative power for local government to regulate commercial activity under town planning and local legislation, under the Liquor Control Act 1988 local authorities also have a planning role with licensed outlets at a community level in relation to public health and amenity concerns. As will be discussed in the local government section, local authorities are more and more becoming involved in mobilizing on behalf of local residents to restrict the operation of licensed premises because of social problems associated with alcohol use, as noted by Buffinton (2014) and discussed by a number of contributions in Stemming the Tide of Alcohol (Manton, Room, Giorgi, \& Thorn, 2014). 
The form and diverse nature of public advertising now present in public spaces is astounding. It includes large free-standing billboards along roads and highways, displays on the sides of buildings, small advertising on signs on footpaths adjoining entrances to licensed premises and bottle shops, and static and illuminated placement on public facilities like bus shelters, street furniture, and kiosks (House of Representatives Standing Committee on Social Policy and Legal Affairs, 2011). Inquiries like those by the House of Representatives have sought to respond to increased community concern about the ubiquitous presence of alcohol advertising in public places on structures, which it is noted occurs without the nuanced levels of restrictions that apply to advertising on television.

A major advantage for industry is that the presence of alcohol advertising in public space enables it to operate outside the strictures inherent in the Alcohol Beverages Advertising Code (ABAC) system, which is considered in the next section. The infiltration of round-the-clock alcohol advertising in public space indicates that one of the long-standing principles adopted to regulate alcohol advertising in the electronic media - "that some segments of the population are especially vulnerable to advertising ... [because they] will be differentially sensitive to advertising or will not have sufficient information or intellectual capacity to counter the persuasive arguments contained in commercials"- -has been abandoned (Fisher, 1993, p. 143). The abandonment of this principle, designed to confine alcohol advertising because it was understood to pose an unacceptable level of risk to a number of groups in the population, seems to have let the industry operate in an unfettered manner.

In WA, as local government "owns" most of the public space, its capability to regulate use of that space is reliant on the Local Government Act 1995. Section 3.5 of this legislation provides local governments with extensive powers through issuing and proclaiming local laws, policies, and codes, as "local government may make local laws under this Act prescribing all matters that are required or permitted to be prescribed by a local law, or are necessary or convenient to be so prescribed, for it to perform any of its functions under this Act" (Local Government Act 1995, Section 33B).

The regulation of alcohol advertising should be a noncontentious proposition, particularly because local government's role in advancing community health would yield tangible community benefit to reduce alcohol-related harm, as it would "denormalise high levels of alcohol consumption which is confounded by the prevalence of alcohol advertising in Australia” (Pettigrew, Johnson, \& Daube, 2013, p. 72).

\section{The problem with the current system}

The Australian system of regulating alcohol advertising cannot be described as a national or comprehensive system, as the federal government's power to regulate advertising is limited to electronic media under the ABAC system. This means there is a spectrum of other forms of advertising that state, territory, and local government are empowered to regulate.

Our current, weak regulatory system has operated for some years as an industry-sponsored system of self-regulation, which has filled the vacuum outside the penumbra of federal regulation and which has been extended by the industry to provide a loose set of principles to also regulate the content of outdoor advertising (Munro, 2006). The regulation of advertising in public consists of an industryoperated framework of codes of practice and principles issued by the Australian Association of National Advertisers, which has established the Advertising Standards Bureau and the Outdoor Media Association (Australian Association of National Advertisers, 2012). These codes apply to all forms of advertising, with some additional provisions drawn from by the ABAC, which is specifically concerned with the regulation of alcohol advertising (Alcohol Beverages Advertising Code Scheme Ltd, 2015).

The ubiquitous nature of advertising in public places, which in recent years has been the fastest growing sector of all advertising in both Australia and overseas (Alcohol Advertising Review Board, 2012; Iveson, 2011), means for example that pedestrians on public thoroughfares or motorists on roads are compelled to view it. The ABAC principles are general in nature, stating that advertisements should present a "mature, balanced and responsible approach to alcohol consumption," should not have a "strong or evident appeal to children or adolescents," or should not "suggest the consumption or presence of alcohol may create or contribute to a significant change in mood or environment” (Advertising Standards Bureau, 2009).

However, industry's interpretation of these general principles has been found wanting on many occasions (Australian National Preventive Health Agency, 2012; Jones, Hall, \& Munro, 2008; Munro, 2006; Pettigrew, Johnson, \& Daube, 2013; Saunders \& Yap, 1991). A submission by Castan Centre for Human Rights Law to the inquiry of the Standing Committee on Social Policy and Legal Affairs into public advertising noted that, as "outdoor advertising occupies a privileged part in the public space," it was a form of public speech or expression that should recognize the appropriateness of culture and place (House of Representatives Standing Committee on Social Policy and Legal Affairs, 2011, p. 19). In the foreword to its report, the Standing Committee recommended there be more comprehensive rules to regulate the content of outdoor advertising:

The Committee considered that outdoor advertising constituted a specific category of advertising because of the way that it occupies public spaces, dominates civic landscape, and targets captive, unrestricted audiences. The inquiry addressed particular concerns about the impact of increasing, cumulative and sustained exposure to advertisements that contain sexual, discriminatory or violent material and to advertisements for alcohol and unhealthy foods and beverages. 
As such, the Committee concluded that industry selfregulation of advertising standards needs to include a specific code of practice for outdoor advertising (House of Representatives Standing Committee on Social Policy and Legal Affairs, 2011, vii).

\section{The rationale for local government regulating advertising in public places}

The power to regulate advertising in public places arises as local government "owns" almost all public space on which the roads, footpaths, seating, bus shelters, and parklands are located. Indeed there has been support for the proposition that local government should regulate the content of all advertising, such as clothing and apparel advertising that utilize strategies sexualizing children and women (Senate Standing Committee on Environment, Communications and the Arts, 2008b; Bailey, 2011).

Local government has a long-standing and well established involvement in public safety, environmental health, the management of public facilities and infrastructure, and maintaining road ways and adjoining footpaths to accommodate the flow and movement of both pedestrians and motor vehicles. It is contended that the proliferation of alcohol advertising in public places, which are largely under the jurisdiction of local authorities, means local government, rather than state or federal government, should play a front-line role in ensuring that community standards and expectations about the use of alcohol are maintained and implemented. As has been noted by Giesbrecht, Bosma, Juras, and Quadri (2014), the engagement of local communities in addressing these consequences underpins mobilizing actions at a local level to deal with alcoholrelated problems.

It may be argued that all forms of alcohol advertising should be prohibited, or that some forms should be permitted while others should not. The difficulties with permitting some forms are evident from the presence of sexist alcohol advertising on bus shelters, such as the recent Becks and Hahn's Dry Dock Premium Lager beer ads, both the subject of adverse community responses. ${ }^{1}$ The high strategic value of being able to advertise alcohol on bus shelters has been recognized in other jurisdictions. An example is of a Michelob beer ad cited by Haas and Sherman (2003), which shares similarities with both the Becks beer and the Hahn's dry dock premium lager, involving sexualization of women.

The proliferation of advertising in public places depends on the willingness of local government authorities to enter into commercial arrangements with media companies, such as APN and Billboards Australia, to erect and maintain billboards, bus shelters, and street furniture. In return for a fixed payment, the local authority grants the operating company the right to offer third-party advertising rights by

\footnotetext{
${ }^{1}$ The Becks ad was criticized in the report by the National Committee for the Review of Alcohol Advertising in August 2003, while the Hahn ad was adjudicated on by the Alcohol Beverages Advertising Code Complaints Panel on 26 May 2011 (Determination 35/11)
}

renting out the sides of the bus shelter, the kiosk, or seating (Emery, 2016).

A compelling commercial advantage for advertising on public structures, compared to highly regulated advertising on television and radio, is that public infrastructure is available 24 hours a day, seven days per week. Another advantage for advertisers is that the audience is unrestricted, whereas the advertising codes developed for TV broadcasting take account of specific time slots based on when children and young people are considered most likely to view programs.

'As outdoor media companies are fond of pointing out to potential advertisers, outdoor is the only medium that you cannot turn off (Hampp, 2007). As such, the regulation of its content is particularly important.' (Iveson, 2010)

An implicit "advantage" of alcohol advertising, from the perspective of industry, is that its pervasive presence "normalizes" alcohol, depicting the consumption of alcohol as a "normal" part of everyday living (Pettigrew, Johnson, \& Daube, 2013). Alcohol Policy UK cited evidence in its "Stick to the Facts" report as justification for regulation of alcohol advertising to

'achieve a "better balance between public health concerns and commercial freedoms. (As) ... advertising creates social norms around alcohol and promotes the normalisation of drinking in society. Exposure to alcohol marketing is linked to consumption, particularly in the under 18's. ... a sensible policy response is needed [including] ... a ban on advertising at all sporting, cultural and music events' (Alcohol Policy UK, 2013).

The proliferation of advertising containing scenarios identifying alcohol's pleasurable consumption inserts the use of alcohol into the fabric of everyday life with its presence on public infrastructure. In its 2012 issues paper, the Australian National Preventive Health Agency ${ }^{2}$ identified how the weak Australian national regulatory framework has permitted extensive exposure to alcohol advertising and thereby normalized the use of alcohol by young people (Australian National Preventive Health Agency, 2012).

Concern that the neutered regulatory regime for advertising and promotion on alcohol across all forms of media has facilitated the increased consumption of alcohol is not confined to Australia (National Alliance for Action on Alcohol, 2014), as advertising has been linked to the growth in alcohol use by young people in the United Kingdom (Hastings, 2010; Hastings \& Angus, 2009) and the United States (European Centre for Monitoring Alcohol Marketing, 2014).

\footnotetext{
${ }^{2}$ The Australian National Preventive Health Agency was abolished in 2014 by the Abbott federal government. (McInerney, 2014).
} 
There are a number of other rationales under which local authorities could exercise oversight on advertising in public places. One of these is road safety; Harold Scruby of the Pedestrian Council of Australia argues that billboard advertising amounts to being "driver distraction by design," as it is intended to "attract the gaze of the driver long enough to create the impression that sells the product. ...The extra distraction of scrolling billboards has just compounded the existing problem of the placement of billboards obstructing sight distances between drivers and pedestrians” (Scruby, 2007).

From a traffic safety perspective, it is debatable whether any form of advertising should be permitted along or visible from roadways, given that it relies upon driver distraction and its presence has the potential to increase the likelihood of motor vehicle-related accidents. Austroads research supports a contention that roadside advertising per se should be regarded as a non-trivial safety hazard, even though there may not sufficient studies to demonstrate this, as "the studies show convincingly that roadside advertising is distracting and that it may lead to poorer vehicle control. However, the evidence is presently only suggestive of, although clearly consistent with, the notion that this in turn results in crashes" (Austroads, 2013).

The power to prohibit roadside advertising because it represents a hazard to drivers is limited to main roads and highways, as Section 33B (1) of the Main Roads Act 1930 enables the Commissioner for Main Roads to designate highways, main roads, and sections or part of a road to control the exhibition of advertisements on or in the vicinity of those roads that are subject to control of access where the "where such hoardings or other advertising structures are considered to be hazardous to traffic safety or are aesthetically objectionable," as described in the Act.

This limitation in Section 33B means local government needs other sources of power to regulate roadside advertising along roads it controls on the grounds of traffic safety (Main Roads Western Australia, 2012). These powers are contained in the Local Government Act 1995 and the Planning and Development Act 2005 and have been used to regulate a wide range of commercial and business activities that impact public space, such as billboards along roads, posters and signs attached to buildings, bus shelters, small free-standing signs outside and adjacent to the entrances of premises and benches, as well as other types of street furniture and buildings over which private firms have the right to display advertising or advertising.

The existence of privately managed public bus shelters in selective locations along major roads is supported by an argument that, as local governments do not have sufficient resources and/or have more important priorities, they should permit private companies to construct and maintain them. However, this argument can result in perverse consequences for some groups in the community, such as the elderly or those with disabilities, as occurred in the City of Stirling:

'City of Stirling bus users will have to swelter through another summer without shelters at many stops because of a stalemate between the city and State Government over who pays for them. The city council confirmed it had not installed any new shelters because of legal advice it got in 2008. The council has shelters at 450 out of more than 1,350 stops in the city.

Public Transport Authority spokesman David Hynes said the bus shelter grants scheme had $\$ 500,000$ available this financial year, with the PTA to contribute up to 50 per cent of the cost for new shelters. Under the scheme, about 50 shelters had been built in partnership with 21 councils in the past year.' (Lacy, 2011)

The consequences of this sort of failure of policy implementation by local government does not seem to match efforts by other levels of government, such as the Department of Infrastructure and Transport (2012), which has promoted and updated disability standards for public transport. The claim that a local authority is unable to fund the provision of bus shelters, as in the example of the City of Stirling, sets up a proposition that councils "need" to resort to funding through private sector arrangements. As the operation of a privately managed bus shelter will be determined on economic grounds, social reasons are likely to be given a low priority.

It should noted that when local authorities have undertaken a strong advocacy role against the expansion of small bars seeking a license to operate under the Liquor Control Act 1988, they have been harshly criticized, such as in the case of the City of Subiaco (Riley, 2007), which has adopted a number of policies and bylaws which include alcoholrelated matters under powers available to it under its town planning scheme (City of Subiaco, 2005; 2010; 2013).

Critics of the City of Subiaco's approach have invoked the concept of "wowserism," a term with a long currency in Australian, as it was originally invoked to deride and argue against those seeking to regulate the use of alcohol through the imposition of restrictions on opening hours (Dunstan, $1968 ; 1988)$. Some of the precepts of wowserism were used to criticize the City of Subiaco's policy to set limitations on the operation of small bars, by imputing that such restrictions spoil fun and prevent people from enjoying themselves:

'A policy restricting new bars within $100 \mathrm{~m}$ of parts of Subiaco's high street could be reviewed within weeks in a move frustrated business owners hope may breathe new life into the suburb. The move comes amid concerns the city is not doing enough to support small business and hospitality in the area, at the expense of its vibrancy.' (Emery, 2014)

It is likely that a local authority that does adopt policies to regulate alcohol advertising in its area would face comparable criticisms on similar grounds, that it was curbing the freedom of business resulting in the loss of a sort of perceived dividend of "vibrancy" that it brought to a community (Candler, 2014; Emery, 2014). The example of one particular local authority, the City of Subiaco, which 
has specifically regulated alcohol advertising, highlights a key consideration that local government involvement in regulating alcohol advertising will depend on the strength of community support for the policy.

With respect to regulating alcohol advertising in public places, this poses some difficulty for local authorities, as the standards for content of advertising are largely determined and controlled by industry-supported arrangements of national codes of practice. These, as noted earlier, though originally established by the alcohol industry to regulate the content of advertising in the electronic media, have been extended to the oversight of the content of advertisements in a different and unrelated context of advertising in public places (Senate Standing Committee on Environment, Communications and the Arts, 2008a).

The public policy concerns from this infusion of business priorities into the provision of public services have been identified in other jurisdictions. For example, a study on the impact of restricting alcohol advertising on public transport in the San Francisco Bay area concluded that "a strong argument against alcohol ads is the value that government property should not be used to provide an opportunity for corporate marketing of potentially dangerous products” (Simon, 2008, p. 515).

We may conclude that even though local authorities have a wide jurisdiction to regulate public space, it is fair to say that the example of the City of Subiaco, which has adopted a restrictive approach towards alcohol and other forms of advertising in public places through creating and defending its alcohol policy framework, is the exception. Without a strong level of commitment by a local authority, muted and ineffectual alcohol policies will operate, resulting in the presence of alcohol-related advertising through commercial arrangements for the construction and maintenance of public infrastructure, such as bus shelters.

\section{Conclusions}

The commercialization of the use of public space described in this paper raises concerns about the adoption by local governments of a model to privately build and maintain public infrastructure, such as bus shelters, in return for their use as sites for the advertising of alcohol, as well as other products and services.

There are concerns about the outcomes from such policies in relation to alcohol in particular, as it appears to have little to do with community needs and much more to do with the priorities and interests of business, resulting in the selective provision of public services. This stems from the shift towards the emergence of market-driven policies reliant on self-regulation as government is regarded as having a circumscribed and limited role in the economy, accompanied by what one commentator has described as being the rise of "permissiveness" and the adoption of "more calculative and reflexive self-controls" (Wouters, 1999, p. 417).
This shift means that a local government authority seeking to assume a larger regulatory role may need to articulate a case for stepping into an arena in which business interests have assumed they have a right to operate with little restriction or hindrance. A number of rationales can be identified from this preliminary review of the potential importance of local government's role in regulating alcohol advertising.

One is that regulating alcohol advertising in public places can draw on public health concerns, as advertising encourages greater use of alcohol through normalization, with attendant increases in public order and health-related harms. Another is that, because there is substantial community concern about the content of advertisements, there is strong support at a local level for local government to adopt a strong regulatory framework. Finally, as local authorities possess substantial statutory powers under local government and town planning laws, these should be regarded as potent instruments to develop policies and establish a framework to regulate the sale and advertising of alcohol.

\section{Acknowledgements}

An early version of this research was presented at the Thematic meeting of the Kettil Bruun Society, Alcohol policy research: Putting together a global evidence base, held in Melbourne, 8-11 September 2014. The author wishes to acknowledge the generous assistance provided through detailed feedback and commentaries from referees over a number of drafts and revisions of this paper.

\section{References}

Advertising Standards Bureau. (2009). Alcohol beverages advertising (and packaging) code. Retrieved from http://www.adstandards.com.au/files/view/?id=173

Alcohol Advertising Review Board. (2012). Alcohol Advertising Review Board Content and Placement Code. Perth, Western Australia: McCusker Centre for Action on Alcohol and Youth, Curtin University. Retrieved from http://www.alcoholadreview.com.au/ resources/Alcohol-Advertising-Review-BoardContent-and-Placement-Code-July-2012.pdf

Alcohol Policy UK. (2013). 'Stick to the facts: Alcohol concern call for tougher regulation on alcohol advertising. Retrieved from www.alcoholpolicy.net/ 2013/08/stick-to-the-facts-alcohol-concern-report-onalcohol-advertising-and-regulation.html

Australian Association of National Advertisers. (2012). AANA Code of Ethics. Retrieved from http://aana.com. au/content/uploads/2014/05/AANA-Code-ofEthics.pdf

Alcohol Beverages Advertising Code Scheme Ltd. (2015). About the ABAC Scheme. Retrieved from www.abac. org.au/about/

Australian Broadcasting Control Board. (1975). Television program standards (2nd ed.). Canberra, Australian 
Capital Territory: Commonwealth Government Printer.

Australian National Preventive Health Agency. (2012). Alcohol advertising: The effectiveness of current regulatory codes in addressing community concerns. Canberra, Australian Capital Territory: Australian National Preventive Health Agency.

Austroads Ltd. (2013). Impact of roadside advertising on road safety. Publication no. AP-R420-13. Sydney, New South Wales, Australia: Author.

Babor, T. F., Caetano, R., Casswell, S., Edwards, G., Giesbrecht, N., Graham, K., ... Rossow, I. (2010). Alcohol no ordinary commodity: Research and public policy. New York, NY, United States: Oxford University Press.

Bailey, R. (2011). Letting children be children: Report of an independent review of the commercialisation and sexualisation of childhood. Final report. Command 8078. London, England: Department for Education.

Buffinton, L. (2014). Community engagement in liquor licensing. In E. Manton, R. Room, C. Giorgi, \& M. Thorn (Eds.), Stemming the tide of alcohol: Liquor licensing and the public interest. Canberra, Australian Capital Territory: Foundation for Alcohol Research and Education.

Candler, R. (2014, November 4-10). Bar approval divides neighbours. Western Suburbs Weekly, 3.

City of Subiaco. (2005). 2.12 Liquor licensing policy. Amended 25 November 2014. Retrieved from www.subiaco.wa.gov.au/CityofSubiaco/media/Cityof-Subiaco/Planning-and-development/Townplanning-controls-and-policies/2-12-LiquorLicensing-Policy_1.pdf

City of Subiaco. (2010). 2.18 Advertising signs policy. Retrieved from www.subiaco.wa.gov.au/ CityofSubiaco/media/City-of-Subiaco/Planning-anddevelopment/Town-planning-controls-and-policies/218-Advertising-Signs-Policy.pdf

City of Subiaco. (2013). City of Subiaco town planning scheme no. 4. Retrieved from www.subiaco.wa.gov. au/CityofSubiaco/media/City-of-Subiaco/Planningand-development/Heritage-news/TPS-4-Scheme-Textas-at-22-May-2015_1.pdf

Department of Infrastructure and Transport. (2012). 2012 Review of the Disability Standards for Accessible Public Transport 2002 (Transport Standards): Issues paper. Canberra, Australian Capital Territory: Department of Infrastructure and Transport.

Dunstan, D. (1988). Boozers and wowsers. In V. Burgmann \& J. Lee (Eds.), Constructing a culture. Fitzroy, Victoria, Australia: McPhee Gribble/Penguin.

Dunstan, K. (1968). Wowsers. North Melbourne, Victoria, Australia: Cassell, Australia.

Emery, K. (2014, August 3). Red tape chokes old favourites: traders. The West Australian. Retrieved from https://au.news.yahoo.com/thewest/a/24619118/ red-tape-chokes-old-favourites

Emery, K. (2016, February 24). Councils chase advertising cash. The West Australian, 19.

European Centre for Monitoring Alcohol Marketing. (2014). US research: Underage drinkers heavily exposed to magazine ads for alcohol brands they consume. Retrieved from www.eucam.info/eucam/ home/news.html/1881/3407/

Fisher, J. C. (1993). Advertising, alcohol consumption and abuse: A worldwide survey. Westport, Connecticut, United States: Greenwood Press.

Giesbrecht, N., Bosma, L. M., Juras, J., \& Quadri, M. (2014). Implementing and sustaining effective alcohol-related policies at the local level: Evidence, challenges and next steps. World Medical \& Health Policy, 6(3), 203-230.

Glance, D., \& Pettigrew, S. (2014, August 18). Time to warn drinkers about the risk of cancer. The Conversation. Retrieved from http://theconversation. com/time-to-warn-drinkers-about-the-risk-of-cancer30609

Haas, A., \& Sherman, J. (2003). Eliminating alcohol advertising on Philadelphia's public property: a case study. Philadelphia, Pennsylvania, Centre on Alcohol Marketing and Youth, Georgetown University. Retrieved from www.researchgate.net/ profile/Julia_ Sherman/publication/242739228_Eliminating_Alcoho 1_Advertising_on_Philadelphia's_Public_Property_A_ Case_Study/links/0deec53c56f4d215b7000000.pdf

Hastings, G. (2010). They'll drink bucket loads of the stuff: An analysis of internal alcohol industry advertising documents. London, England: Alcohol Education \& Research Council. Retrieved from http://alcoholresearchuk.org/downloads/finalReports/ AERC_FinalReport_0071.pdf

Hastings, G., \& Angus, K. (2009). Under the influence: The damaging effect of alcohol marketing on young people. London, England: British Medical Association.

House of Representatives Standing Committee on Social Policy \& Legal Affairs. (2011). Reclaiming public space: Inquiry into the regulation of billboard and outdoor advertising. Canberra, Australian Capital Territory: Australian Parliament.

Iveson, K. (2011). Branded cities: Outdoor advertising, urban governance and the outdoor media landscape. Antipode: Radical Journal of Geography, 44(1), 151174. Retrieved from www.geosci.usyd.edu.au/ documents/people/branded_cities.pdf

Iveson, K. (2010). Submission to inquiry into the regulation of billboard and outdoor advertising. Parliament of Australia: House of Representatives, 12. Retrieved from www.aph.gov.au/house/committee/spla/outdoor \%20advertising/subs/Sub\%2046.pdf

Jones, S. C., Hall, D., \& Munro, G. (2008). How effective is the revised regulatory code for alcohol advertising in Australia? Drug \& Alcohol Review, 27, 29-38.

Lacy, B. (2011, December 21). Bus shelter row heats up. The West Australian. Retrieved from http://au.news. yahoo.com/thewest/a/-/breaking/12423772/busshelters-row-heats-up/

Main Roads Western Australia. (2012). Guidelines for determining and assigning responsibility for roads in Western Australia. Western Australia: Road Asset Planning Branch, Main Roads Western Australia. Retrieved from https://www.mainroads.wa.gov.au/ Documents/UIDELINES\%20FOR\%20DETERMININ G\%20AND\%20ASSIGNING\%20RESPONSIBILITY 
\%20FOR\%20ROADS\%20IN\%20WA\%20\%20websit e\%20version\%20March\%202012.u_3640516r_1n_D1 2\%5E23.PDF

Manton, E., Room, R., Giorgi, C., \& Thorn, M. (Eds.). (2014). Stemming the tide of alcohol: Liquor licensing and the public interest. Canberra, Australian Capital Territory: Foundation for Alcohol Research and Education.

McInerney, M. (2014, 1 September). The demise of the ANPHA: why it will be 'drinks all around' for the alcohol industry and others. Crikey. Retrieved from http://blogs.crikey.com.au/croakey/2014/09/01/why-itwill-be-drinks-all-round-for-the-alcohol-industry-andothers-when-the-anpha-shuts-its-doors/

Munro, G. (2006). A decade of failure: Self-regulation of alcohol advertising in Australia. The Globe, 3, 15-18. Retrieved from www.ias.org.uk/resources/ publications/theglobe/globe200603/gl200603_p15. html

National Alliance for Action on Alcohol. (2014). The impact of alcohol marketing on children: The evidence and need for immediate action. Retrieved from $<$ www.actiononalcohol.org.au/downloads/call-toaction-on-alcohol-advertising.pdf $>$

National Committee for the Review of Alcohol Advertising. (2003). Review of the self regulating system for alcohol advertising: Report to the Ministerial Council of Drug Strategy. Victoria, Australia: Minister for Health Victoria. Retrieved from

http://docs.health.vic.gov.au/docs/doc/2E4E141E5A71 9092CA2578A1000A1CB0/\$FILE/ncraareport.pdf

Outdoor Media Association. (2012). Outdoor Media Association's Code of Ethics. Retrieved from http://oma.org.au/_data/assets/pdf_file/0019/2458/O MA_Code_of_Ethics_May_2012.pdf

Pennock, P. E. (2007). Advertising sin and sickness: The politics of alcohol and tobacco marketing 1950-1990. DeKalb, IL, United States: Northern Illinois University Press.

Pettigrew, S., Johnson, R., \& Daube, M. (2013). Introducing and applying a New Australian alcohol advertising code. Journal of Public Affairs, 13(1), 7283.

Riley, S. (2007, July 27). Subiaco Plan Sinks Liquor Laws (2007). ClubConnect. Retrieved from www.clubconnect.com.au/news/2007/07/news13022.a sp

Saunders, B., \& Yap, E. (1991). Do our guardians need guarding? An examination of the Australian system of self-regulation of alcohol advertising. Drug \& Alcohol Review, 10, 15-27.

Scruby, H. (2007). Roadside advertising - A driver distraction by design. In I. J. Faulks, M. Regan, M. Stevenson, J. Brown, A. Porter, \& J. D. Irwin (Eds.), Distracted driving. Sydney, New South Wales, Australia: Australasian College of Road Safety.

Senate Standing Committee on Environment, Communications and the Arts. (2008a). The effectiveness of the broadcasting codes of practice. Canberra, Australian Capital Territory: Senate, Australian Parliament. Retrieved from http://www.aph.gov.au/binaries/senate/committee/eca _ctte/broadcasting_codes/report/report.pdf

Senate Standing Committee on Environment, Communications and the Arts. (2008b). Sexualisation of children in the contemporary media. Canberra, Australian Capital Territory: Senate, Australian Parliament. Retrieved from http://www.aph.gov.au/ binaries/senate/committee/eca_ctte/sexualisation_of_c hildren/report/report.pdf

Simon, M. (2008). Reducing youth exposure to alcohol ads: Targeting public transit. Journal of Urban Health: Bulletin of New York Academy of Medicine, 85(4), 506-516.

Wouters, C. (1999). Changing patterns of social controls and self-controls: On the rise of crime since the 1950s and the sociogenesis of a "Third Nature." British Journal of Criminology, 39(3), 416-432.

\section{Legislation}

Western Australia

Liquor Control Act 1988

Local Government Act 1995

Main Roads Act 1933

Planning and Development Act 2005

Commonwealth Australian

Broadcasting and Television Act 1942-1969 